\title{
Development of business processes of distance educational activities at higher educational institutions using the experience of foreign countries against the backdrop of pandemic (by the example of MSTUCA)
}

\author{
Anastasiia Kachalova ${ }^{1 *}$ \\ ${ }^{1}$ Moscow technical university of civil aviation, Moscow, Russia
}

\begin{abstract}
This article examines the problem of distance educational activities at higher educational institutions against the backdrop of pandemic. The article compares the work of foreign HEIs and the results of their activities. Particular attention is paid to distance education at Russian HEIs, including the Moscow State Technical University of Civil Aviation. The characteristic features of business processes of distance educational activities at the university using applied programs are determined and described. This problem has been little studied and requires further research.
\end{abstract}

Today, when the strategic and, perhaps, the key resource is not capital, but information and knowledge, the role of the educational system increases significantly. And the main priority of education is not only and not so much the ability to convey systematized and important information, but also to teach students to independently find and analyze the necessary information, as well as to apply it in further activities, regardless of the specialty [1]. Adaptation of the educational process to new conditions and future challenges will allow minimizing the possible increase in unemployment, as well as ensure the availability of necessary human resources for the developing areas of the Russian digital economy, which today is gaining more and more importance and relevance. The digital economy is understood as a system of economic, social and cultural relations based on the use of digital technologies. At the present stage of improving the current, medium- and long-term development of higher education system, the higher education and the national economy are synchronized, moving towards a single direction, of development, which implies combining objectives for increasing the GDP growth rate, the quality of services provided, and, as a result, people's quality of life [2].

According to the Federal Law No. 273-FZ dated December 29, 2012 "On Education in the Russian Federation", "by distance educational technologies are meant educational

\footnotetext{
* Corresponding author: a.kachalova@mstuca.aero
} 
technologies implemented mainly with the use of information and telecommunication networks with indirect (distanced) interaction between students and teachers" [3].

Until March 2020, educational organizations used distance technologies in the implementation of educational programs rather as an additional means to traditional forms of education: for extra-mural students, for those studying under some additional educational programs according to an individual education plan, during short periods of annual influenza quarantine in some regions of Russia. But the situation dictated new terms to educational organizations - due to the COVID-19 virus pandemic, the educational process went into a fully distance mode for an indefinite time. However, the transition from the traditional system to distance education turned out to be a little easier due to the fact that earlier programs were adopted and decrees were issued in the Russian Federation regarding the gradual transformation of education in higher educational institutions. So, the national program "Development of Digital Economy in Russia - a Program until 2035" was adopted in the Russian Federation in 2017 [4]. According to this program, the digital economy is defined as "a set of social relations developed by using electronic technologies, electronic infrastructure and services, technologies for analyzing large amounts of data and forecasting in order to optimize and increase the level of countries' social and economic development."

The decrees of the President of the Russian Federation, such as "Strategy for the Development of the Information Society in the Russian Federation for 2017-2030" [5] and "On National Goals and Strategic Objectives of the Development of the Russian Federation for the Period until 2024" [6], provide for the implementation of a number of national projects, including the education project.

The summary of the education project includes the following tasks:

training more than 10 million people in programs for the development of digital literacy in the system of distance education technologies;

introduction of certain elements of the Digital University model in $100 \%$ of government organizations in 2023;

increase in the number of Russian universities in global international rankings and moving of the Russian Federation from the 17th place, taken in 2019, to the 10th place by 2025 by the number of universities represented in the TOP-500 of the global ranking.

According to the most authoritative Times Higher Education ranking, which presented the results of the leading ranking of world universities for 2020, among more than 1,300 universities in 92 countries, 39 Russian universities are represented in the list. Of these, only 5 are represented in the TOP-500: Lomonosov MSU - 189, MIPT - 201-250, Higher School of Economics - 251-300, ITMO University - 401-500, MEPhI - 401-500 [7].

Thanks to modern information and communication technologies, all components of the educational process can be transferred to an electronic environment and use the advantages of electronic learning.

In order to bring the traditional educational system to the system described in the decrees above, the start point should be determined.

First of all, it should be realized, which business processes are taking place in a higher educational institution and which ones require changes on a first-priority basis. Processes in the HEI are divided into management, main and supporting processes.

This paper will consider the main processes. The main processes are diverse and include pre-university training, attracting students, educational activities, employment of graduates, additional education, scientific and innovative activities, international activities and external interaction, cooperation.

Within the framework of improving distance education using modern technologies, the most interesting processes in terms of study are attracting students, educational activities 
and additional education. But their development is absolutely impossible without improving the quality and process management processes.

Attracting students and their further admission remotely gained rapid development in 2020. The Ministry of Science and Higher Education of the Russian Federation has prepared and launched the program "Online Admission to Higher Educational Institutions", which allowed applicants to submit all the necessary documents for admission to HEI for bachelor's and specialist's programs remotely. In the summer of 2020, applicants could apply for admission to 54 Russian HEIs. This opportunity was used by more than 20 thousand applicants, having submitted about 70 thousand applications. This program is one of the most striking instance of the digital university transformation.

One of the important problems that arose as a result of the COVID-19 pandemic is the problem of organizing not just distance education, but distance education without loss of quality.

In this situation, it is especially interesting to study the experience of foreign colleagues, and, possibly, use it to improve our own system. Absolutely all HEIs were transferred to distance education: some of them send assignments to the students by mail, not in an interactive mode, and then check their fulfillment online, while others provide full, highintensity and well-structured online education.

It was during the pandemic that Indian universities and colleges finally realized the importance of distance education and online learning, and the current crisis provided a wide range of opportunities to accelerate the introduction of digital technologies. Many HEIs use the SWAYAM integrated learning platform developed by the government and SWAYAM PRABHA educational channels. Many HEIs also give classes via Google Meet and Zoom. However, these innovations have only confirmed the inequalities in higher education. This idea is reflected in the recent letter from Suranjan Das, head of Jadavpur University in Kolkata, to the employees. According to The Telegraph newspaper, Das urged colleagues to exercise good judgment about online classes and the distribution of digital educational materials He asked teachers to take into account the socioeconomic status of students, many of whom cannot afford to buy a home computer. The Das's message emphasizes the fact that the issues of equality and fairness should not be ignored in the development of online education: in Indian cities, $97.94 \%$ of the population has Internet coverage, while in rural areas, only $25.36 \%$ of the population has access to the Internet [8].

For comparison, as reported by the Federal State Statistics Service of the Russian Federation, in $2019,79.9 \%$ of the population have access to the Internet in households in urban areas, and $67.7 \%$ in rural areas [9].

According to UNESCO, the closure of universities in Africa affected about 9.8 million students. Due to the danger of the spread of the virus, HEIs have switched to online education. But this is not so easy on the continent, where only $24 \%$ of the population has access to the Internet, which is accompanied by very poor quality of communication, astronomical costs and constant power outages. To solve these issues, an increasing number of universities in Rwanda, Tunisia and South Africa are negotiating with Internet service providers and authorities to provide free access to a number of educational and information websites. At the institutional level, some government HEIs, such as the KwaZulu-Natal University in South Africa, as well as private ones, such as the Ashesi University in Ghana, pay for the Internet access for students and staff [10].

The situation in some Latin American countries turned out to be not so sad. For example, the situation with distance higher education in Argentina differs favorably from the situation in other countries of the region. This form of education has developed rapidly since the beginning of this century thanks to several universities that have found themselves at the forefront of events. By 2017, the university sector had reached a certain maturity required to develop a single regulatory framework in the field of distance education in 
accordance with the accepted quality standards and equalize the status of distance education in comparison with traditional in-person education. The University Board, which includes all universities of the country, together with the Office of University Affairs (SPU) has developed a regulatory framework that enshrines the requirements for distance education. After that, each higher educational institution offering fully or partly distance programs had to develop its own "institutional system of distance education", which, in turn, had to be approved by the SPU, subject to the acknowledgement by the National Commission for Attestation and Accreditation of Universities [11].

A surprisingly smooth transition from in-person to online education has been made possible in Australia thanks to large investments in Learning Management Systems (LMS) in recent years and the digitalization of administrative processes [12].

Perhaps the most interesting experience is that of Chinese colleges and universities. Firstly, the pandemic began in China and, as a result, it was China's HEIs that were the first to completely transfer to online education. And secondly, China's higher education system is the largest in the world: in 2019, it numbered 2,688 colleges and universities and more than 30.3 million students. For comparison, according to a short statistical compilation presented by the HSE University, in 2019, there were 724 educational institutions of higher education in the Russian Federation, and the total number of students at the beginning of the academic year was slightly more than 4 million [13]. Online education is nothing new for Chinese colleges and universities, as it has been used earlier in addition to traditional inperson classes.

Nowadays, there are three main forms of online education in China: MOOC, real-time interactive online learning, and video courses. The MOOC system is a massive open online course that is public accessible on the Internet. As for real-time interactive learning, this is the newest pedagogical method used. Online teaching in China is now widespread. And despite the fact that most teachers had no online experience, they enthusiastically began teaching their courses online during this challenging time [14].

According to foreign experience, MOOC can be considered the most effective international form of distance education. The most striking example of such platform is Stanford University's Coursera project. Today, the number of its users is 75 million, and the number of courses reaches 4.5 thousand in 480 specializations from two hundred educational institutions. After completing courses and passing tests and exams, students receive full-fledged certificates. The Russian Federation has Russian National Platform of Open Education (NPOE), which successfully operates on the basis of the HSE University and currently includes 661 courses in various fields of study from leading Russian higher educational institutions with the number of students amounting to $1,618,000$. For comparison, in January 2020, the Open Education platform offered a total of 436 courses, and the number of students amounted to 1,116,000. To date, Moscow State Technical University of Civil Aviation is not a partner of this platform. However, in order to improve distance education of this HEI and increase its competitiveness, the possibility of further integration into this project can be considered.

In Russia, a massive transition to distance education took place on March 17, 2020, which led to changes in the education system at absolutely all of its levels, but at that time not all academic disciplines were available in a distance format. Each teacher had the opportunity to independently choose an electronic platform for providing online training for students. The transition to distance education has had a significant increase in the number of educational disciplines available in electronic format on the platforms of massive open online courses. Teachers of the Moscow State Technical University of Civil Aviation have successfully developed and implemented electronic training courses using distance technologies for in-person and extra-mural education. To improve the interaction between 
teachers and students, a wide range of virtual communication platforms were used, such as Skype, Zoom, Microsoft Teams, e-mail, forums, chats.

In the long term, when the situation will go back to normal, HEIs should consider integrating online learning into the regular educational process. To begin with, students can be obliged to take part of the courses in a distance form, as is already the case in some traditional universities. For higher educational institutions, this will mean that they simply keep pace with the development of digital culture, which is taking an increasingly prominent place in our society.

\section{References}

1. B.B. Artyukhin Modeling of distance learning business processes using global networks: diss. ... Ph.D.: 08.00.13, Moscow, p. 177 (2004)

2. M.V. Kivarina, L.P Sazhneva and I.A. Borisova Vestnik of Institute of economics and management NovSU Adaptation of high education system to the circumstances of digital economy, v. 2(27), pp. 46-52 (2018)

3. About education in RF: Fed. law v. 273-FL [pass State Duma 29.12.2012 with the changes of 2020 ed. 31.07.2020

4. The development of digital economy in Russia - prospectus to 2035

5. The strategy of the information society development in Russian Federation 20172030: Russian Federation Presidential Decree of 09.05.2017 v.203

6. About national objectives and strategic issues of Russian Federation development until 2024: Russian Federation Presidential Decree of 07.05.2018 v.204

7. M. Agranovich, Russian newspaper Capital Issue Labeled as standout, v.205 (2019)

8. El. Mathews International Higher Education: Russian version of the information circular International Higher education (Boston College, USA), India's Higher Education and Covid-19: Responses and Challenges v.102 special edition (Moscow: CInST HSE), pp. 23-25 (2020)

9. Digital economy: 2020: a brief statistical compendium ed G. Abdrahmanova, K. Vishnevskiy (Moscow: CInST HSE), p.112 (2020)

10. W. Tamrat and D. Teferra, International Higher Education: Russian version of the information circular International Higher education (Boston College, USA), COVID-19 Threat to Higher Education: Africa's challenges, responses and apprehensions, v.102 special edition (Moscow: CInST HSE) pp. 28-30 (2020)

11. M. Marquina, International Higher Education: Russian version of the information circular International Higher education (Boston College, USA), The Argentine University against COVID-19: old and new discussions in an unforeseen reality, v.102 special edition (Moscow: CInST HSE), pp. 34-36 (2020)

12. B. Leask and Chr. Ziguras, International Higher Education: Russian version of the information circular International Higher education (Boston College, USA), The impact of COVID-19 on Australian higher education, v.102 special edition (Moscow: CInST HSE) pp. 36-38 (2020)

13. Russia in numbers 2020

14. D. Bie and J. Liu International Higher Education: Russian version of the information circular International Higher education (Boston College, USA), Temporary Action or new model Experiment? Teaching at Chinese Universities in the time of COVID-19, v.102 special edition (Moscow: CInST HSE) pp. 19-21 (2020) 